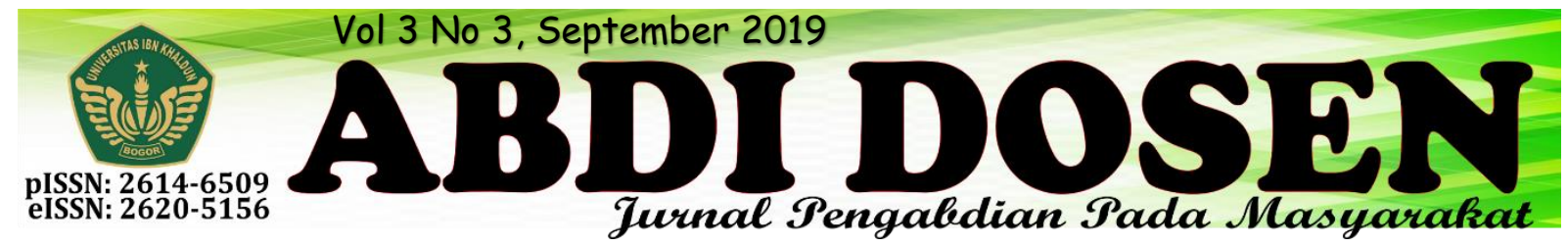

\title{
PENGOPTIMALAN POTENSI MASYARAKAT MELALUI SIKAP PRODUKTIFITAS DAN MANDIRI UNTUK MEMBANGUN KAMPUNG RAMAH LINGKUNGAN DI DESA SITU DAUN
}

\author{
Ikhwan Hamdani ${ }^{1}$, Yossa Adrian Nifaqih ${ }^{2}$ \\ ikhwan@fai.uika-bogor.ac.id \\ Fakultas Agama Islam Universitas Ibn Khaldun', Mahasiswa KKN Kelompok 08 Tahun $2018^{2}$
}

\begin{abstract}
ABSTRAK
Kulian Kerja Nyata (KKN) Mahasiswa/i Universitas Ibn Khaldun merupakan salah satu bentuk pengabdian pada masyarakat yang sesuai dengan Tridarma Perguruan Tinggi dan mengacu pada pedoman 158/IIIa/KR-KKN/UIKA/2013 tentang KKN Universitas Ibn Khaldun Bogor. produktivitas merupakan suatu ukuran yang menyatakan bagaimana baiknya sumber daya diatur dan dimanfaatkan untuk mencapai hasil yang optimal (Herjanto Wikipedia). Sikap mandiri merupakan kemampuan seseorang untuk bertanggung jawab atas apa yang dilakukan tanpa membebani orang lain. (Tri 2014). Dengan membangun kedua sikap tersebut maka diyakini akan adanya perubahan didalam diri masyarakat dan akan memberikan dampak kepada desa/lingkungan. Dalam hal ini KKN Kelompok 3 memiliki tujuan untuk membangun Kampung Ramah Lingkungan, diketahhui bahwa Kampung ramah lingkungan merupakan Suatu lokasi yang masyarakatnya melakukan upaya atau tindakan nyata dalam perlindungan dan pengelolaan lingkungan hidup secara terukur dan berkesinambungan. (Dinas Lingkungan Hidup). Untuk mewujudkan tujuan tersebut, metode yang digunakan (1) Pendekatan melalui karakter masyarakat, (2) Pendekatan Organisasi dan dalam proses kami mengumpulkan informasi menggunakan metode Wawancara dan Data Sekunder. Dengan hasil yang dicapai pada program yang kami jalankan merupakan solusi bagi permasalahan desa dan akan memberikan manfaat dalam jangka waktu dekat, menengah dan jangka panjang, sehingga dapat mewujudkan kampung ramah lingkungan di Desa Situ Daun.
\end{abstract}

Kata Kunci : Produktifitas, Mandiri, dan KLR (Kampung Ramah Lingkungan)

\section{PENDAHULUAN}

\section{Latar Belakang}

Kuliah Kerja Nyata (KKN)

Mahasiswa/i Universitas Ibn Khaldun merupakan salah satu bentuk pengabdian pada masyarakat yang sesuai dengan Tridarma Perguruan Tinggi dan mengacu pada pedoman 158/IIIa/KRKKN/UIKA/2013 tentang KKN Universitas Ibn Khaldun Bogor. Kuliah Kerja Nyata merupakan salah satu bentuk pendidikan yang dilakukan dengan cara memberi pengalaman belajar kepada masyarakat untuk hidup di tengah-tengah masyarakat di luar kampus, bersama masyaraat mengidentikasi dan menangani masalah-masalah pembangunan yang dihadapi.

Pelaksanaan KKN juga bertitik tolak pada landasan pemikiran bahwa Universitas Ibn Khaldun Bogor merupakan bagian yang 
tidak terpisahkan dari masyarakat. Oleh karena itu UIKA memiliki tanggung jawab untuk berpartisipasi dalam pembangunan di tengah-tengah masyarakat. Partisipasi tersebut dilaksanakan dalam bentuk mendidik, melatih, dan mempersiapkan mahasiwanya agar menjadi sarjana yang mampu berperan aktif dan memberikan menfaat dalam membangun masyarakat, yaitu sebagai pemimpin, inovatir, fasilitator, organisator, dan penyuluh pembangunan yang handal.

Program KKN yang dilaksanakan di Desa Situ Daun, Kecamatan Tenjolaya, Kabupaten Bogor, disesuaikan melalui investarisasi potensi dan permasalahan yang ada. program yang dilakukan terbagi menjadi dua yaitu program Desa dan program partisipasi aktif pada kegiatan yangg dilakukan oleh masyarakat dan pemerintah kabupaten Bogor.

Pelaksanaan program KKN diharapkan berperan dalam peningkatan kesejahteraan masyarakat melalui pemberdayaan masyarakat dan optimalisasi pemanfaatan sumberdaya yang ada. dalam pelaksanaannya, mahasiswa diharapkan dapat mandiri dalam melaksanakan kegiatan dan mampu menimba pengalaman dan belajar dari situasi dan kondisi yang ada pada masyarakat untuk kemudian cepat tanggap terhadap persoalan yang timbul, kemudian berusaha menyelesaikannya.

\section{Permasalahan yang dihadapi}

Permasalahan yang dihadapi masyarakat RT.18/04 Kp.Pasir Ipis Desa Situ Daun Kecamatan Tenjolaya Kabupaten Bogor terbagi menjadi empat aspek permasalahan yaitu dalam aspek Lingkungan dan Sosial, Aspek Pendidikan, Aspek Ekonomi dan Aspek Kesehatan.

Dari keempat aspek tersebut terdapat beberapa masalah yang harus di pecahkan dan diselsaikan. Permasalahan diselesaikan melalui program kerja yang kami rancang. Dan untuk memahami lebih mendalam mengenai permasalahan Desa Situ Daun di jelaskan pada bab berikutnya yaitu Identifikasi Masalah.

\section{Solusi yang ditawarkan}

Pembangunan Berkelanjutan. Konsep berkelanjutan merupakan konsep yang sederhana namun kompleks, sehingga pengertian keberlanjutan pun sangat multidimensi dan multi-interpretasi. Karena adanya multi-dimensi dan multi-interpretasi ini, para ahli sepakat untuk sementara mengadopsi pengertian yang telah disepakati oleh Komisi Brundtland yang menyatakan bahwa "Pembangunan berkelanjutan adalah pembangunan yang memenuhi kebutuhan generasi saat ini tanpa mengurangi kemampuan generasi mendatang untuk memenuhi kebutuhan mereka" (Fauzi, 2004).

Konsep Desa Hijau. Desa hijau adalah Desa yang sehat dan bersahabat. Desa yang diisi oleh orang-orang dan atau penduduk yang aktif dan bersahabat dengan lingkungan. Desa dibangun dengan memanfaatkan ruang publik yang lebih alami dan tidak membahayakan kesehatan dan keselamatan penduduknya. Desa hijau harus efisien dan cerdas. BalaiDesa dan bangunan pemerintah harus dibangun dengan konsep hijau. Pemanfaatan air harus bijak. Penggunaan energi sebaiknya dengan memanfaatkan sumber daya alam terbarukan. Desa harus dibangun dengan menerapkan jasa lingkungan sebesarbesarnya sebagai topangan ekonomi. Desa dibangun dengan memaksimalkan jasa sebagai modal pembangunan dengan memanfaatkan sumber daya manusia yang dimilikinya (Joga, 2013).

Dari kedua konsep tersebut diyakini dapat mewujudkan Kampung Ramah Lingkungan melalui gerakan berorientasi 
pada isu kultural dengan implementasi strategi yang beragam dan dengan berbagai faktor saling bekerja sama mewujudkan suatu perubahan di masyarakat.

\section{Geografis}

Desa Situ Daun terletak di wilayah denah ketinggian 332 Meter di atas permukaan laut, dengan koordinat latitude: -6 37'10.99" longitude: 106 42'21.99" serta dengan luas wilayah 329.045 Ha, yang terdiri dari 4 dusun dengan 4 Rukun Warga (RW) dan 21 Rukun Tetangga (RT), Desa Situ Daun memiliki batas wilayah administratif sebagai berikut :

\begin{tabular}{|c|l|c|}
\hline No & Keterangan & Berbatasan \\
\hline 1 & Darat & $159 \mathrm{Ha}$ \\
\hline 2 & Sawah & $170,045 \mathrm{Ha}$ \\
\hline 3 & Utara & $\begin{array}{c}\text { Desa Cihideung } \\
\text { Udik Kec. Ciampea }\end{array}$ \\
\hline 4 & Selatan & $\begin{array}{c}\text { Desa Gunung } \\
\text { Mulya Kec. } \\
\text { Tenjolaya }\end{array}$ \\
\hline 5 & Barat & $\begin{array}{c}\text { Desa Cibitung } \\
\text { Tengah dan Desa } \\
\text { Cinangneng }\end{array}$ \\
\hline 6 & Timur & $\begin{array}{c}\text { Desa Purwasari } \\
\text { Kec. Dramaga }\end{array}$ \\
\hline
\end{tabular}

Desa Situ Daun merupakan desa yang berada di daerah lereng gunung Halimun Salak sebelah selatan, dengan ketinggian antara 332 M, DPL (Diatas Permukaan Laut). Sebagian besar wilayah Desa Situ Daun adalah lahan pertanian dan sisanya lahan kering dan pemukiman.

Aspek Hidrologi Desa Situ Daun membentuk pola Daerah Aliran Sungai (DAS) yaitu sungai Cihideung dan sungai Cinangneng tercatat sebagai solokan baik skala kecil, sedang dan besar terdapat di Desa Situ Daun. Ada beberapa sumber mata air yang bisa digunakan sebagai sumber mata air bersih bagi masyarakat, sumber mata air untuk pertanian maupun untuk perikanan.

Peruntukan lahan pada Desa Situ Daun sebagai berikut :

\begin{tabular}{|c|c|c|}
\hline \multicolumn{2}{|c|}{ Keterangan } & Luas (Ha) \\
\hline Sawah & Teknis & 20 \\
\cline { 2 - 3 } & 1/2 Teknis & 50 \\
\hline \multirow{4}{*}{ Darat } & Perikanan & 13 \\
\cline { 2 - 3 } & Hutan Rakyat & 0.5 \\
\cline { 2 - 3 } & Pekarangan & 10.4 \\
& Pemukiman & \\
\cline { 2 - 3 } & Lain-lain & 5.17 \\
\hline
\end{tabular}

Kepadatan/KM² rata-rata rumah tangga dan Sex Ratio

Penduduk Desa Situ Daun berdasarkan data terakhir kepadatan 2017 sebanyak 9.721, tahun 2016 sebanyak 8.584. Desa Situ Daun Terbagi menjadi 4 Rukun Warga dan masing-masinng RW membawahi 20 Rukun Tetangga (RT). Dengan jumlah Rumah Tangga, Kepadatan $/ \mathrm{KM}^{2}$ rata-rata rumah tangga dan Sex Ratio Desa Situ Daun Sebagai Berikut:

\begin{tabular}{|l|c|c|c|}
\hline No & $\begin{array}{c}\text { RW/ } \\
\text { Kampung }\end{array}$ & $\begin{array}{c}\text { Jumlah } \\
\text { Rumah } \\
\text { Tangga }\end{array}$ & $\begin{array}{c}\text { Kepadatan } \\
\text { Per KM }^{2}\end{array}$ \\
\hline 1 & RW 01 & 479 & $2,1 \%$ \\
\hline 2 & RW 02 & 663 & $5,2 \%$ \\
\hline 3 & RW 03 & 849 & $2,5 \%$ \\
\hline 4 & RW 04 & 675 & $1,5 \%$ \\
\hline \multicolumn{2}{|c|}{ Jumlah } & $\mathbf{2 . 6 6 6}$ & \\
\hline
\end{tabular}

Dengan Jumlah Penduduk laki-laki dan perempuan

\begin{tabular}{|l|c|c|}
\hline Jenis Kelamin & Jumlah & Persentase \\
\hline Laki - laki & 4919 & $50,7 \%$ \\
\hline Perempuan & 4802 & $49,3 \%$ \\
\hline JUMLAH & 8.721 & $100 \%$ \\
\hline
\end{tabular}

\section{Sarana dan Prasarana}

Sarana dan Prasarana di Desa Situ Daun akan disajikan dalam bentuk tabel sebagai berikut: 


\begin{tabular}{|c|c|}
\hline Sarana Pendidikan & Jumlah \\
\hline TK & 2 \\
\hline RA & 1 \\
\hline PAUD & 6 \\
\hline TKA/TPA & - \\
\hline Play Grup & - \\
\hline SD Negeri & 2 \\
\hline SD Swasta & - \\
\hline MI & 3 \\
\hline SLTP Negeri & - \\
\hline $\begin{array}{l}\text { SLTP } \\
\text { Swasta/Tsanawiyah }\end{array}$ & 3 \\
\hline SLTA & 2 \\
\hline PKBM & 1 \\
\hline Paket A & 1 \\
\hline Paket B & 1 \\
\hline Paket C & 1 \\
\hline Pondok Pesantren & 6 \\
\hline Lainnya & - \\
\hline $\begin{array}{l}\text { SLTP } \\
\text { Swasta/Tsanawiyah }\end{array}$ & 3 \\
\hline SLTA & 2 \\
\hline
\end{tabular}

Dapat dilihat pada tabel di atas pendidikan mayoritas dengan lembaga pendidikan anak usia dini dan pondok pesantren, di RW. 04 khususnya RT.18/04 Sendiri hanya memiliki Pendidikan MI saja selebihnya sarana pendidikan tersebar di luar RT.18/04.

\section{Sarana dan Prasarana Keagamaan}

\begin{tabular}{|l|l|c|}
\hline No. & \multicolumn{1}{|c|}{ Jenis } & Jumlah \\
\hline 1 & Masjid Jami & 13 \\
\hline 2 & Langgar/Mushola & 14 \\
\hline 3 & Pondok Pesantren & 6 \\
\hline 4 & Gereja & - \\
\hline
\end{tabular}

Perlu diketahui di setiap mushola ada kegiatan majlis ta'lim di setiap minggunya dan terbagi menjadi beberapa jenis majlis ta'lim yaitu majlis ta'lim ibu-ibu dan majlis ta'lim pemuda/i dengan masing-masing nara sumber yang berbeda.

Prasarana Tempat Usaha

\begin{tabular}{|l|c|}
\hline \multicolumn{1}{|c|}{ Jenis } & Jumlah \\
\hline Konveksi & 27 \\
\hline Bengkel & 18 \\
\hline Kios Bensin & 27 \\
\hline Warnet & 6 \\
\hline Toko & - \\
\hline Waserda & 1 \\
\hline Warung & 48 \\
\hline Penggilingan Padi & 5 \\
\hline Pengrajin Gelasan & - \\
\hline Pengrajin Makanan Ringan & 71 \\
\hline Tambal Ban & 6 \\
\hline Counter Pulsa & 12 \\
\hline Pengemudi Ojeg & 76 \\
\hline BUMDES & - \\
\hline Penjual Makanan Matang & 10 \\
\hline Warung Sate & 2 \\
\hline Loket Pembayaran Listrik & 2 \\
\hline Pertukangan & - \\
\hline Biro Jasa & - \\
\hline Penjahit & 34 \\
\hline Lainnya & - \\
\hline
\end{tabular}

Sarana dan prasarana Tempat Usaha memiliki banyak potensi untuk membantu perkembangan perekonomian masyarakat jika di tata kelola dengan baik dan serius dengan ini perlunya di bangun sikap produktifitas dan kemandirian masyarakat dalam mengembangkan usahanya untuk mencapai kesejahteraan ekonomi.

Prasarana Olahraga

\begin{tabular}{|l|c|}
\hline \multicolumn{1}{|c|}{ Jenis } & Jumlah \\
\hline Lapangan Sepak Bola & 2 \\
\hline Lapangan Bola Volly & - \\
\hline Lapangan Tenis Meja & 6 \\
\hline Lapangan Bulu Tangkis & 5 \\
\hline
\end{tabular}

Sarana Olahraga merupakan fasilitas yang di berikan oleh pemerintah desa untuk dapat di manfaatkan oleh masyarakat dengan tujuan menambah kesehatan dan kebugaran tubuh masyarakat. 


\section{Potensi Wilayah Sasaran}

Pada permasalahan lingkungan dimana permasalahan penglolaan sampah adalah permasalahan yang sangat mencolok. Akan tetapi permasalahan ini dapat di selesaikan dengan memberikan sarana dan prasarana bagi warga untuk dapat mengelola sampah secara mandiri karena sesuai dengan pengamatan yang kami lakukan khususnya warga RT.18/04 Desa Situ Daun memiliki peluang yang besar untuk dapat di arahkan dan di bina. serta sikap warga yang terbuka dan mudah untuk di ajak ikut serta dalam berbaagai kegiatan, sehingga dapat dengan mudah untuk mengarahkan warga dalam pengelolaan sampahnya.

Warga Desa Situ Daun memiliki potensi untuk di kembangkan dalam bidang pendidikan, namun kesadaran akan pentingnya pendidikan belum sampai dikalangan remaja sehingga banyak remaja yang putus sekolah karena permasalahan ekonomi dan kurangnya keinginan untuk melanjutkan sekolah sehingga memilih untuk menikah. Pada dasarnya setiap manusia memiliki potensinya masingmasing namun pendidikan juga merupakan salah satu hal penting untuk mengembangkan potensi yang dimiliki.

Berdasarkan tabel 2.2C sarana dan prasarana dalam bidang usaha, Desa Situ Daun memiliki potensi yang sangat besar untuk pertumbuhan ekonomi karena banyaknya jenis usaha yang dijalankan oleh masyarakat terutama di bidang pengrajin makanan setelah pengemudi ojek. Kondisi ini dapat di manfaatkan secara maksimal yaitu apabila setiap warga memiliki kreatifitas dalam mengelola peluang yang ada, contohnya sumber daya alam berupa sayuran sawi hijau (secim) yang menjadi sumber daya alam andalan bagi masyarakat Desa Situ Daun. Selain itu banyaknya jumlah tenaga pencari kerja dan lowongan kerja yang besar menjadi potensi yang besar pula untuk pembangunan bisnis. Dengan pembangunan bisnis maka akan menyerap beberapa persen dari angkatan kerja tersebut, untuk lebih jelasnya dapat dilihat pada tabel berikut :

\begin{tabular}{|c|l|c|}
\hline No & \multicolumn{1}{|c|}{ Yang Terdaftar } & Jumlah \\
\hline 1 & Pencari Kerja & 1.978 \\
\hline 2 & Yang Ditempatkan & 660 \\
\hline 3 & Lowongan Kerja & 660 \\
\hline 4 & Sisa Pencari Kerja & 1.516 \\
\hline \multicolumn{2}{|c}{ Potensi lainnya di bidang Kesehatan, }
\end{tabular}

kesehatan warga Situ daun dapat dikatakan baik khususnya di RT.18/04 karena pada saat kegiatan POSYANDU dilakukan di RT.18/04 tidak adanya balita yang kekurangan gizi ataupun balita yang memiliki badan yang masuk kedalam kategori kerdil. Hal tersebut dikatakan oleh kader posyandu Melihat potensi kesehatan yang baik maka diyakini apabila kegiatan posyandu tersebut di lakukan secara rutin maka kesehatan bagi balita akan terus meningkat. 


\section{METODE PELAKSANAAN}

Tahap Pelaksanaan

Pelaksanaan KKN kelompok 3 Desa

Situ Daun ini terhitutng dari tanggal 7 Agustus 2018 sampai dengan tanggal 5
September 2018 dengan tahapan pelaksanaan permingu, berjumlah 4 tahapan. Adapun tahap pelaksanaan sebagai berikut:

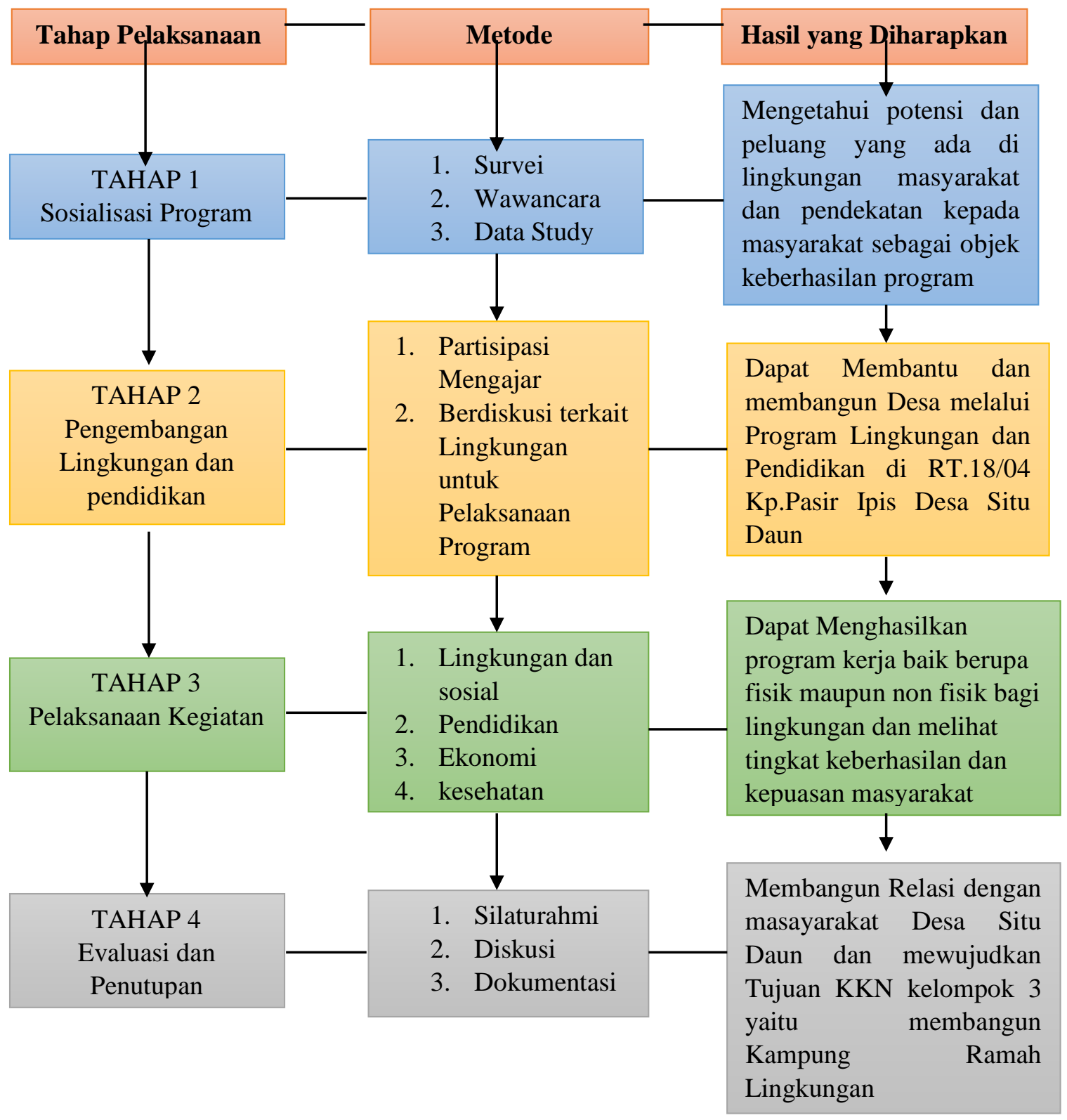


Dari hasil tahapan program di atas maka tersusunlah beberapa program yang dijalankan. Program tersebut dibagi kedalam 4 minggu pelaksanaa, sebagai berikut :Tabel 3.1A Jadwal Kegiatan KKN Kelompok 3

\begin{tabular}{|c|c|c|c|c|c|}
\hline \multirow{2}{*}{ No } & \multirow{2}{*}{ Kegiatan } & \multicolumn{3}{|c|}{ Minggu } & \multirow{2}{*}{ Ket. } \\
\hline & & 1 & 3 & 4 & \\
\hline 1 & Penyusunan Rencana Kegiatan & & & & Terlaksana \\
\hline 2 & Sosialisasi Rencana Kegiatan & & & & Terlaksana \\
\hline 3 & $\begin{array}{l}\text { Pembuatan tugu KKBPK (kependudukan, } \\
\text { keluarga berencana, dan pembangunan } \\
\text { keluarga) }\end{array}$ & & & & $\begin{array}{c}\text { Bekerjasama } \\
\text { Dengan KKBPK }\end{array}$ \\
\hline 4 & $\begin{array}{l}\text { Seminar Pembinaan dan pelatihan } \\
\text { P2WKSS (Peningkatan Peran Wanita } \\
\text { menuju Keluarga Sehat dan Sejahtera) } \\
\text { tingkat provinsi Jawa Barat } 2018\end{array}$ & & & & $\begin{array}{c}\text { Bekerjasama } \\
\text { Dengan Pemerintah } \\
\text { Daerah Kab.Bogor }\end{array}$ \\
\hline 5 & $\begin{array}{llll}\begin{array}{l}\text { Pembuatan } \\
\text { Keluarga) }\end{array} & & & \text { TOGA } \\
\end{array}$ & & & & Terlaksana \\
\hline 6 & Penyuluhan Menabunng Sejak Dini & & & & Terlaksana \\
\hline 7 & $\begin{array}{l}\text { Partisipasi mengajar di Lingkungan } \\
\text { (mengajar di Mi Sirojul Huda) }\end{array}$ & & & & Terlaksana \\
\hline 8 & Pengukuran Anak di POSYANDU & & & & Terlaksana \\
\hline 9 & Pembuatan Bank Sampah & & & & Terlaksana \\
\hline 10 & $\begin{array}{l}\text { Penyembelihan dan Pemberian daging } \\
\text { Hewan Kurban untuk Desa }\end{array}$ & & & & Terlaksana \\
\hline 11 & $\begin{array}{lcr}\text { Kerja Bakti } & \text { Bersama warga untuk } \\
\text { mewujudkan } & \text { Kampung } & \text { Ramah } \\
\text { Lingkungan } & & \\
\end{array}$ & & & & Terlaksana \\
\hline 12 & $\begin{array}{l}\text { Belajar Membaca Al-Qur'an dan Bimbel } \\
\text { Khusus Bahasa Asing (Bahasa Arab dan } \\
\text { Bahasa Inggris) }\end{array}$ & & & & Terlaksana \\
\hline 13 & $\begin{array}{l}\text { Pelatihan Pembuatan Keripik sawi dan } \\
\text { Bros kain Perca }\end{array}$ & & & & Terlaksana \\
\hline 14 & Market Day & & & & Terlaksana \\
\hline 15 & $\begin{array}{l}\text { Training Motivas kepada anak-anak } \\
\text { dengan tema "Don't Bullying to your } \\
\text { Friend" }\end{array}$ & & & & Terlaksana \\
\hline 16 & $\begin{array}{l}\text { Pemberian Buku Kepada Taman Baca } \\
\text { (Perpustakaan Mini) }\end{array}$ & & & & Terlaksana \\
\hline 17 & BAKSOS baju Bekas & & & & Terlaksana \\
\hline 18 & $\begin{array}{l}\text { Pembutan sarana dan Prasarana } \\
\text { (penunjuk) untuk jalan RT.18/04 }\end{array}$ & & & & Terlaksana \\
\hline 19 & Pembuatan Jalan Refleksi & & & & Terlaksana \\
\hline 20 & Monitoring dan Evaluasi & & & & Terlaksana \\
\hline
\end{tabular}




\begin{tabular}{|c|l|l|l|l|l|}
\hline 21 & $\begin{array}{l}\text { Penutupan dan perpisahan KKN bersama } \\
\text { Warga dan Lembaga Terkait }\end{array}$ & & & & Terlaksana \\
\hline 22 & Penyusunan Laporan KKN & & & & Terlaksana \\
\hline
\end{tabular}

\section{Metode Pendekatan}

Pendekatan yang digunakan pada kegiatan ini adalah dengan pendekatan pembangunan karakter masyarakat melalui sikap produktifitas dan mandiri untuk setiap individu. Dimana dalam pendekatan ini terdiri dari 3 aspek yaitu: (1) Pendekatan Faktor Manusia (2) Pendekatan Motivasi (3) Pendekatan Lingkungan. Ketiga aspek tersebut dilihat dari sudut pandang pembangunan karakter untuk mewujudkan kampung ramah lingkungan di Desa Situ Daun.

Adapun strategi yang dilakukan dalam pelaksanaan program kerja melalui beberapa pendekatan yang strategis, diantaranya:

1. Pendekatan melalui karakter masyarakat, yakni melalui pembinaan yang dilakukan akan disesuaikan dengan karakter masyarakat setemat. Soemarmo Soedarsono (2010) mengarti-kan karakter adalah nilai-nilai yang terpatri dalam diri kita melalui pendidikan, pengalaman, percobaan, pengorbanan dan pengaruh lingkungan yang dipadukan dengan nilai-nilai dari dalam diri manusia sehingga menjadi semacam nilai intrinsik yang mewujud dalam sistem daya juang yang melandasi pemikiran, sikap dan perilaku kita.

2. Pendekatan Organisasi, menurut Masmuh dapat digunakan beberapa pendekatan yaitu pendekatan makro, pendekatan mikro, pendekatan individual, pendekatan ilmiah, pendekatan hubungan antarmanusia, pendekatan sistem dan pendekatan kultural. (Masmuh, 2010; 35). Dalam pendekatan organisasi kami lebih menggunakan pendekatan makro. Pendekatan makro organisasi dipandang sebagai suatu struktur global yang berinteraksi dengan lingkungannya, Baik organisasi dalam kelompok kami maupun organisasi yang ada di lingkungan RT.18/04 dan organisasi pemerintahan Desa Situ Daun.

Dalam pelaksanaan menjawab permasalah Desa langkah yang ditempuh menggunakan beberapa sumber data yang kami dapatkam melalui beberapa metode pengumpulan data, yaitu:

1. Wawancara

Proses tanya Jawab lisan dimana dua orang atau lebih bertatap muka secara fisik untuk mengetahui tanggapan, pendapat, dan motivasi seseorang terhadap suatu obyek. Wawancara dapat dipakai sebagai cara pengumpul data dengan jalan tanya jawab sepihak yang dikerjakan dengan sistematis dan berlandaskan kepada tujuan penelitian. Data yang kami dapatkan dengan proses wawancara berbagai pihak yaitu warga RT.18/04, Ketua RT.18, Bapak Desa Situ Daun dan Staff pemerintahan kantor Desa Situ Daun.

2. Data Sekunder

Pengumpulan data selanjutnya menggunakan pengumpulan data sekunder yaitu data-data atau informasi yang diberikan oleh Kantor desa mengenai keadaan Desa Situ Daun berupa berkas tertulis dengan isi data terbaru dan relefan. Melalui data tersebut kami dapat mengidentifikasi permasalahan Desa Situ Daun serta 
memberikan solusi yang terbaik untuk pembangunan Desa.

\section{Partisipasi Masyarakat dalam Program}

Adapun beberapa partisipasi masyarakat Desa Situ Daun khususnya RT.18/04 dalam mengsukseskan program kerja kami yakni sebagai berikut:

1. Bersedia menjadi narasumber kerkait dengan pengumpulan data yang kami perlukan.

2. Bersedia diwawancarai terkait dengan pelaksanaan program.

3. Menyediakan tempat untuk kegiatan program berupa seminar, pelatihan, pendidikan dan program lainnya.

4. Menjadi rekan kerjasama dalam menjalankan program kerja

5. Ikut berpartisipasi aktif dalam program yang di laksanakan.

6. Bersedia memberikan pendapat dan ikut serta berdiskusi untuk pencapaian keberhasilan program kerja

\section{Langkah Evaluasi}

Beberapa evaluasi yang akn dilakukan adalah sebagai berikkut:

1. Evaluasi masukan meliputi pertimbangan tentang sumber dan strategi yang diperlukan untuk mencapai tujuan terlaksananya program. Data dan informasi yang terkumpul selama tahap

\section{HASIL DAN PEMBAHASAN}

\section{Pelaksanaan Program}

Pelaksanaan program ini

dilaksanakan oleh seluruh tim pelaksana yang terbagi kedalam 4 bidang yang terlampir dalam lampiran susunan kepngurusan. Adapun pelaksanaan program adalah sebagai berikut:

\section{Bidang Lingkungan dan Teknik}

Program kerja yang dirancang pada bidang lingkungan dan Teknik dapat memecahkan beberapa permasalahan yang pelaksanaan hendakanya dapat memberikan gambaran untuk menentukan sumber dan strategi di dalam keterbatasan dan hambatan yang ada. data dan informasi Desa seharusnya tersusun dengan baik dan lebih terperinci.

2. Evaluasi Proses, dalam evaluasi ini terkait dengan perencanaan, pelaksanaan dan monitoring kegiatan. Evaluasi proses dilakukan setiap selesainya program kerja yang dijalankan hal ini dilakukan demi mengukur tingkat keberhasilan program dan dampak yang akan dirasakan oleh masyarakat setelah adanya program tersebut.

3. Evaluasi hasil penilaian dalam mengukur pencapaian program persikap fisik dan non fisik, penilaian tersebut dikembangkan dan diadministrasikan. Sehingga data yang dihasilkan dapat berguna untuk anggota dan masyarakat setempat dalam menentukan apakah program dapat di teruskan, dimodivikasi atau di hentikan. Evaluasi ini dapat digunakan untuk memberikan penilaian manfaat atas program yang telah dilakukan serta memberikan dampak kepada masyarakat baik dalam dangka pendek, menenngah dan jangka panjang.

muncul di Desa Situ Daun terkait dengan Lingkungan dan Teknik. 


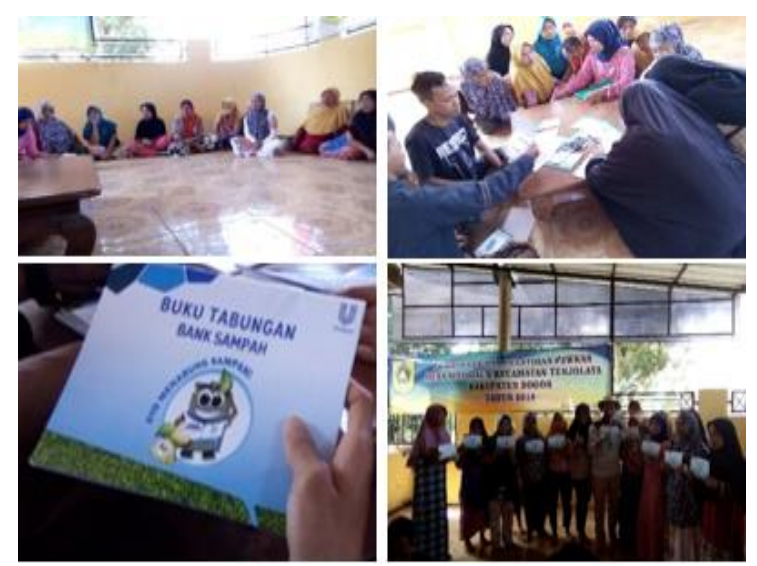

1.Program Pembuatan Bank Sampah

Merupakan salah satu upaya untuk memecahkan masalah dalam pengelolaan sampah rumah tangga oleh warga Desa Situ Daun khususnya Kp, Pasir ipis Rt.18/04. Tujuan:

- Membangun sikap mandiri

- untuk menyadarkan masyarakat akan lingkungan yang sehat, rapi, dan bersih.

- untuk mengubah sampah menjadi sesuatu yang lebih berguna dalam masyarakat

- membuat sampah menjadi barang ekonomis dan menambah penghasilan warga setempat

- menciptakan kampung yang ramah lingkungan melalui pengelolaan sampah

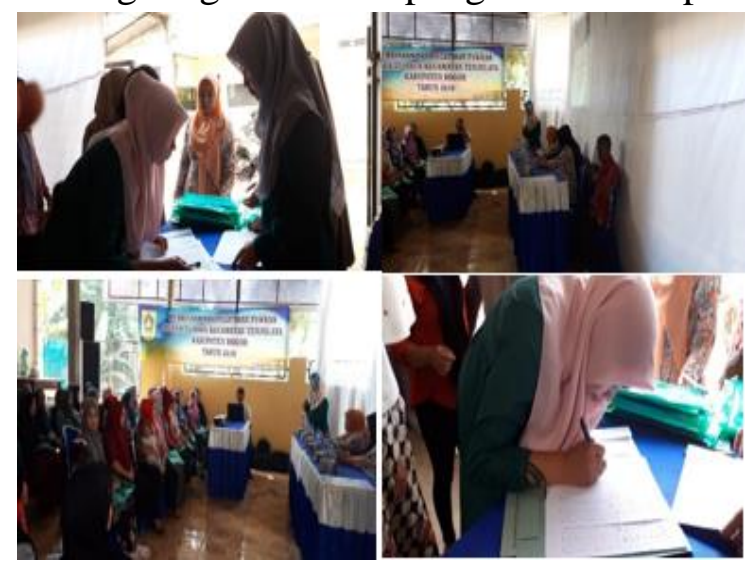

2.Seminar Pembinaan dan pelatihan P2WKSS

Pembinaan dan pelatihan P2WKSS di laksanakan untuk melatih dalam membina keluarga yang di tunjukan kepada satu Desa yang dipilih oleh pemerintah Daerah kabupaten Bogor. Seminar ini dilakukan berdasarkan beberapa kriteria yaitu seminar dilakukan kepada desa yang memiliki tingkat KB yang rendah, tingkat ekonomi yang rendah dan tingkat pendidikan yang rendah, tujuan:

- Untuk meningkatkan taraf hidup yang lebih layak.

- Memberikan pelatihan kepada ibu-ibu dalam membangun keluarga sehat dan sejahtera.

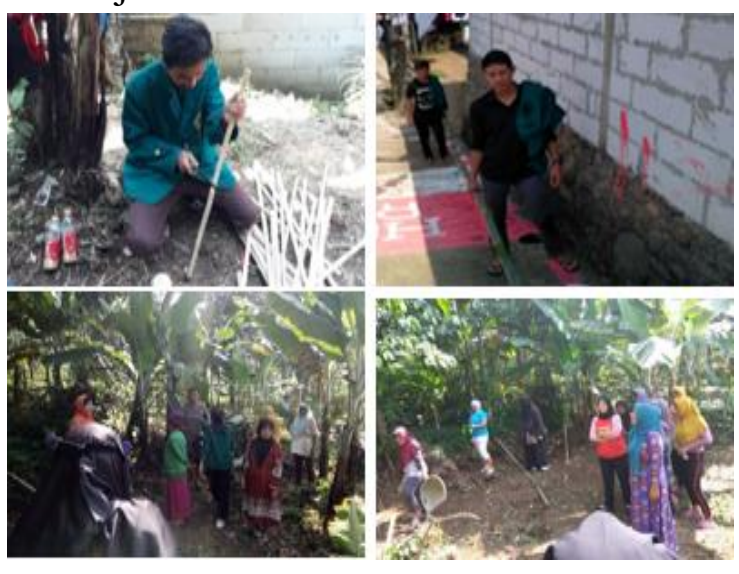

3.Kerja Bakti Bersama warga untuk mewujudkan Kampung Ramah Lingkungan

Kerja bakti dilakukan untuk membangun lingkungan yang lebih bersih serta membangun silaturahmi dan kekompakan warga. Kerjabakti pertama dilakukan dengan penanaman sejumlah pohon di beberapa titik rawan longsor, tempat penanaman pohon di tentukan oleh Pak RT.18.

kerja bakti kedua dilakukan dengan pengecoran jalan menuju rumah pak RT.18, tempat tersebut dipilih untuk di cor/perbaiki karena jalannya yang sudah tidak lagi rata dan bagus serta bebatuan yang tidak beraturan. Tujuan:

- Mempererat talisilaturahmi warga sekitar

- Membangun lingkungan hijau dan mencegah longsor 
- Memberikan fasilitas jalan yang lebih baik

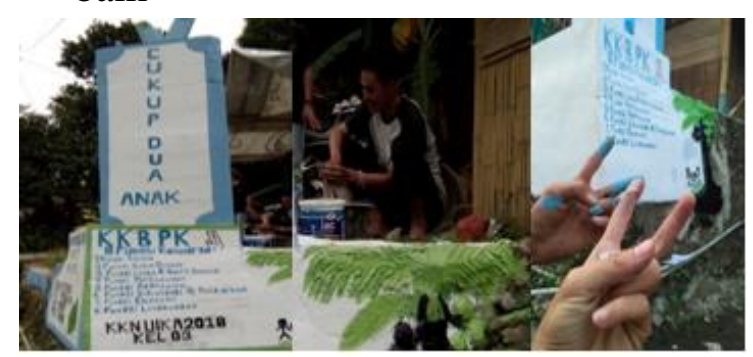

\section{Pembuatan tugu}

Tidak adanya Icon tanda pengenal Desa dan sebagai alat pengingat bagi masyarakat untuk memiliki Keluarga Berencana yaitu merencanakan banyaknya jumlah anggota keluarga atau jumlah anak yang di inginkan karena banyak warga yang tidak menggunakan KB (Keluarga Berencana). Tujuan:

- Memberikan Icon kampung

- Sebagai alat pengingat bagi masyarakat dalam berKB

- Upaya dalam menciptakan keluarga yang terencana

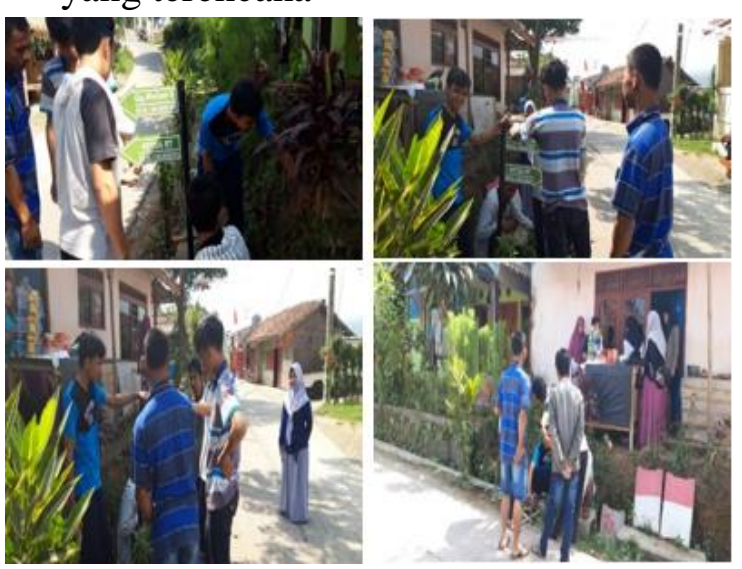

\section{Pembutan sarana dan Prasarana}

Kurangnya sarana dan prasarana penunjuk jalan di RT.18/04 maka dengan ini kami membanngun sarana dan prasarana tersebut agar mempermudah warga /masyarakat luar Desa dalam mencari alamat. Tujuan:

- menambah sarana dan prasarana Desa

- mempermudah masyarakat dalam pencarian alamat

\section{Bidang Pendidikan dan Agama}

Program kerja yang dirancang pada Bidang Pendidikan dan agama dapat memecahkan beberapa permasalahan yang muncul di Desa Situ Daun terkait dengan pendidikan dan Agama serta dapat memotivasi masyarakat khususnya Anakanak dan remaja yang sedang menjalankan pendidikannya.
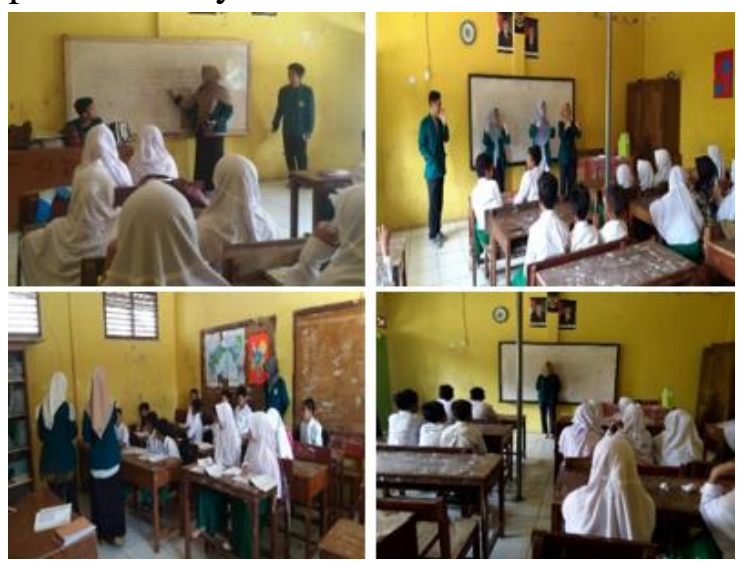

1.Kegiatan Mengajar di Sekolah MI (Madrasah Ibtidaiyah)

Berbagi Ilmu pengetahuan dan wawasan keIslaman terutama dalam bidang penanaman dan pengembangan akhlak mulia serta motivasi mencari ilmu/pendidikan kepada murid di sekolah. Kegiatan ini didasari dari hasil wawancara dengan kepala sekolah MI tersebut, menyatakan bahwa krisisnya akhlak mulia pada siswa-siswi MI Sirojul Huda.

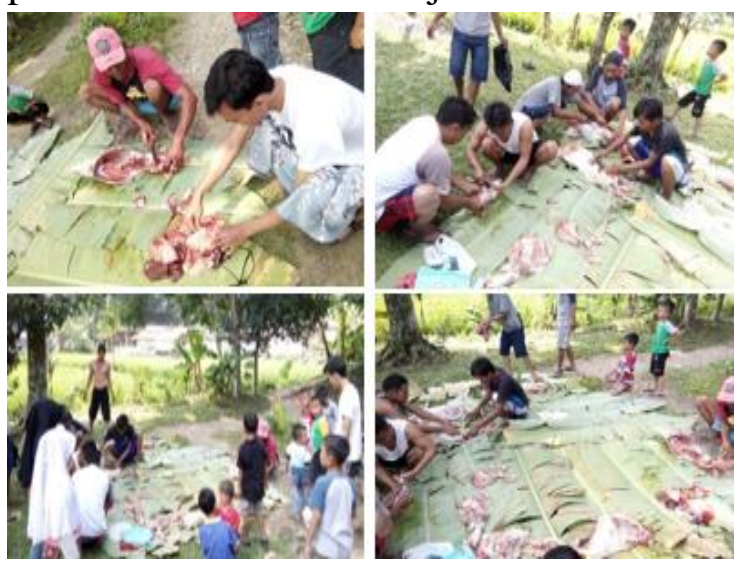

\section{Pemberian Hewan Kurban Untuk Desa}

Berbagi kebahagian dalam Hari Raya Idhul Adha di Desa merupakan bukti kepekaan sesama. Maka kegiatan ini hadir 
dari insiatif kami setelah kami mewancarai beberapa masyarakat, mengemukakan bahwa di Desa tersebut sangat jarang dan sedikit pembagian daging hewan kurban. Oleh karena itu kami mencoba menjadi bagian yang dapat mensalurkan kebahagian di Hari Raya dengan pembagian daging hewan kurban melalui para donatur untuk maasyarakat Desa.

Tujuan: Masyarakat dapat merasakan nilai dari adanya Hari Raya Idhul Adha dengan adanya kegiatan penyembelihan hewan kurban. Serta bisa merasakan kebahagiaan di Hari Raya Idhul Adha.
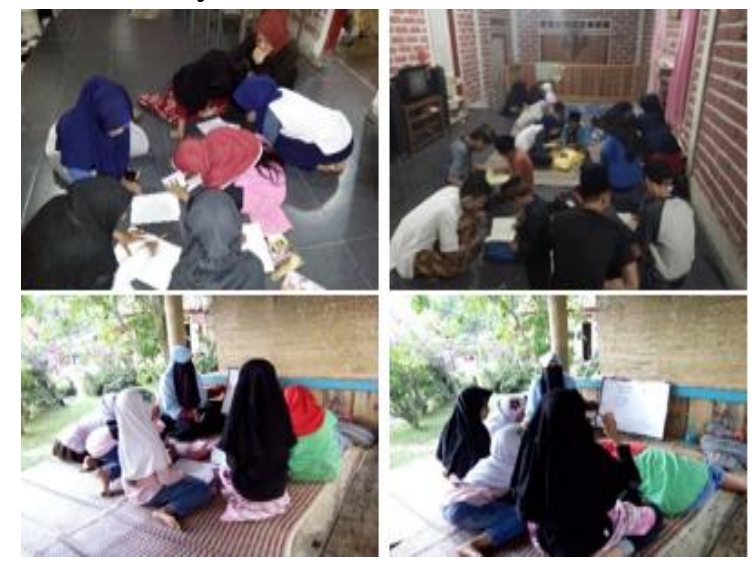

3.Belajar Membaca Al-Qur'an dan Bimbel Khusus Bahasa Asing (Bahasa Arab dan Bahasa Inggris)

Membaca Al-Qur'an dengan baik dan benar sesuai kaidahnya merupakan keharusan dan kewajiban bagi seorang muslim, karena ia merupakan pedoman pertama dan utama umat Islam. Oleh karena itu, kami hadir sebagai wadah mencoba untuk memperbaiki bacaan anak-anak dn remaja desa. Bahasa Inggris adalah bahasa Internasional dan Bahasa Arab adalah bahasa Al-qur'an dan pengantar ilmu keIslaman. Namun sungguh sangat disayangkan, banyak kami temui kurangnya minat anak-anak dalam kebahasaan karena persepsi mereka bahasa itu rumit dan susah. Maka kami hadir mencoba membuka jalan kerumitan mereka dan solusi kesusahan mereka dalam belajar kebahasaan tersebut dengan metode-metode yang menyenangkan dan menarik.

Tujuan: Anak-anak dan remaja mampu membaca Al-Qur'an dengan baik dan benar. Sedangkan dalam kebahasaan kami mengharap anak-anak tumbuh keminatan dan kesenangan mempelajari bahasa Arab \& Inggris sebagai bahasa yang dapat mengantarkan mereka menjelajahi dunia untuk mencari ilmu serta dapat dijadikan sarana berdakwah.

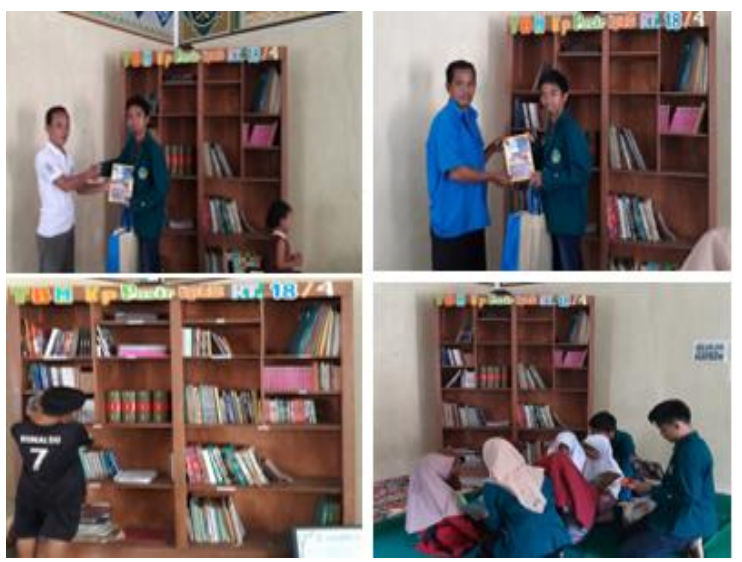

4.Pemberian Buku Kepada Taman Baca (Perpustakaan Mini)

adanya Taman Baca yang sudah didirikan tahun 2017 lalu membuat kami ingin meneruskan dan melestarikannya. Serta jumlah buku-buku yang tersedia di taman baca masih sedikit maka dengan ini kami menambah koleksi/jumlah buku tersebut. Dengan adanya buku-buku baru yang kami berikan diharapkan dapat memberikan semangat baru untuk anakanak dan remaja dalam membaca dan memanfaatkan buku, tujuan:

- Membangun minat membaca bagi anak-anak, remaja dan dewasa

- Memotivasi masyarakat untuk mempertahankan budaya baca buku, karena buku adalah jendela dunia

5.Training Motivas kepada anak-anak dengan tema "Don't Bullying to your Friend"

Bullying sesama teman pasti akan banyak kita temui di sekolah, dampaknya 
pun sangat membahayakan keberlangsungan hidup dan masa depan orang yang terkena bullying. Oleh karena itu, kami mengadakan agenda ini untuk membagi informasi, membuka dan menyadarkan akan bahaya bullying. Serta tidak lupa menyadarkan bahwa perbuatan bullying termasuk perbuatan tercela atau buruk yang dapat mengurangi eksistensi sebagai seorang muslim.

Tujuan: Siswa-siswi dapat mengetahui, memahami dan tersadar bahaya bullying sesama teman. Hingga akhirnya mereka menjahui dan mengisolasi bullying dari perilaku dan pribadi mereka dan lahirlah perilaku mulia

\section{Bidang Ekonomi}

Program kerja yang dirancang pada Bidang Ekonomi di sesuaikan dengan potensi dan permasalahan Desa di Bidang Ekonomi, adapun beberapa program kerja yang dijalankan dan dapat memberikan manfaat kepada masyarakat Desa Situ Daun khususnya Kp.Pasir Ipis RT.18/04.

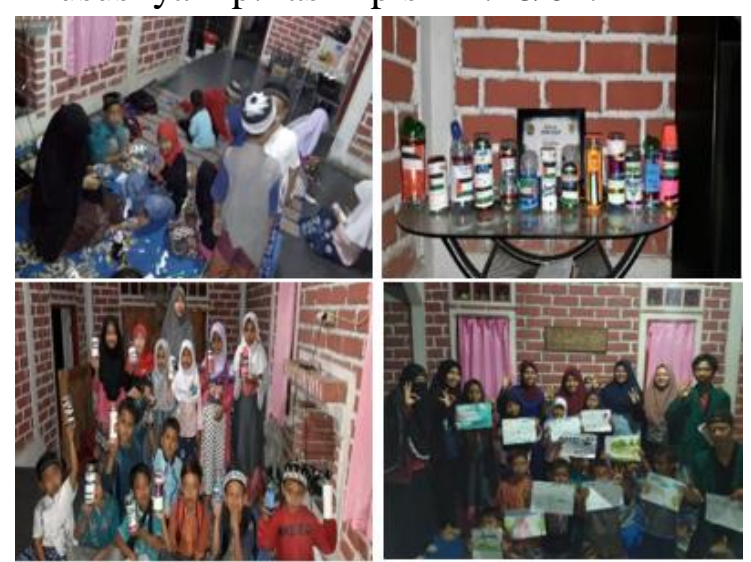

\section{Penyuluhan Menabung Sejak Dini}

Banyaknya anak-anak menggunakan uang saku yang diberikan orang tua untuk jajan tanpa menyisihkan uang saku karena kurangnya pemahaman untuk menabung dan berhemat. Maka dengan ini kami membangun sikap anak-anak untuk dapat berhemat dengan menyisihkan uang saku yang diberikan oleh kedua orang tuanya dan dengan membangun mental mandiri dalam menajerial keuangan. Tujuan:

- Membangun sikap mandiri

- Mendidik anak untuk berhemat

- Mendidik anak dalam manajerial keuangan

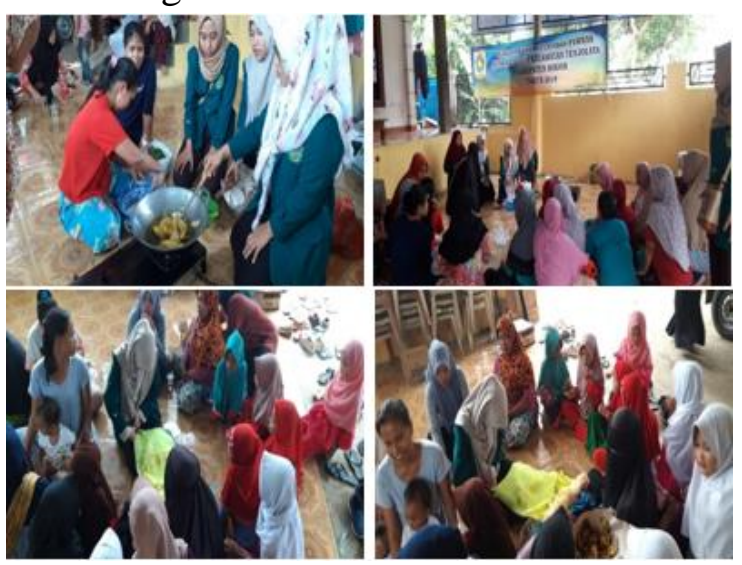

2.Pelatihan Pemanfaatan Sumber Daya Alam

Melihat potensi Sumber Daya Alam di bidang pertanian Desa Situ Daun adalah Sayuran Sawi. Dimana sayuran sawi tersebut hanya di panen dan langsung dijual tanpa adanya produk olahan sawi. Sebenarnya sawi dapat dijadikan produk olahan makanan dengan nilai ekonomi yang lebih tinggi. Dengan ini kami membuat sebuah program inovasi dengan memanfaatkan sayuran sawi untuk menambah keterampilan warga dalam memanfaatkan SDA yang ada, serta menambah penghasilan warga dengan adanya produk olahan sawi yang dijual ke pasaran. Dan juga Pemanfatkan kain perca yang dapat dijadikan produk ekonomis untuk warga desa Siu Daun. Tujuan:

- Memberikan peluang usaha

- Menambah penghasilan warga

- Menumbuhkan jiwa wirausaha 

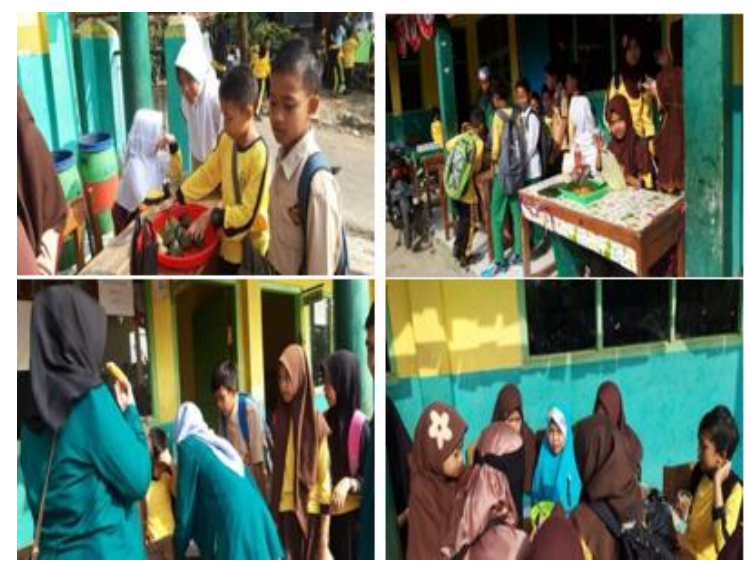

\section{Market Day}

Melihat kini mental anak-anak yang malu untuk berjualan atau berbisnis kecil dan permasalahan di Bidang Ekonomi mengenai Angkatan Kerja maka dengan ini kami membuat program market day untuk memberikan pelajaran dan bimbingan bangaimana cara berbisnis dengan sederhana dan asik tanpa harus malu dan memberikan motivasi untuk pemuda Angkatan Kerja bahwa Bisnis dapat dimulai dari mana saja asalakan adanya keinginan dan semangat berbisnis. Tujuan:

- Membangun mental wirausaha

- Memotivasi dan memberikan peluang usaha

- Menumbuhkan jiwa wirausaha

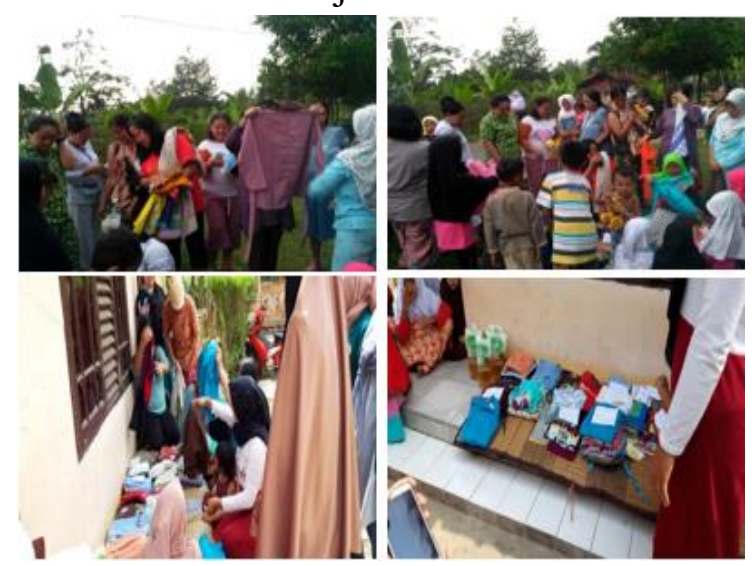

\section{BAKSOS Baju Layak Pakai}

Jauhnya jarak warga dan kondisi ekonomi yang belum sejahtera serta sedang berlangsungnya renovasi mushola di Kp.Pasir ipis kami membuat program BAKSOS pakaian layak pakai untuk membantu bagi warga yang ingin membeli pakain namun keadaan tidak memungkinkan dan hasil dari penjualan Baju layak pakai di sumbangkan 100\% kepada mushola yang sedang salam tahap renovasi, tujuan:

- Membantu renovasi mushola dengan penghasilan BAKSOS

- Membangun sikap tolong menolong

\section{Bidang Kesehatan}

Program kerja di Bidang Kesehatan di sesuaikan dengan permasalahan dan kebutuhan masyarakat Desa Situ Daun, adapun beberapa program kerja yang dijalankan dan dapat memberikan manfaat kepada masyarakat Desa Situ Daun khususnya Kp.Pasir Ipis RT.18/04.

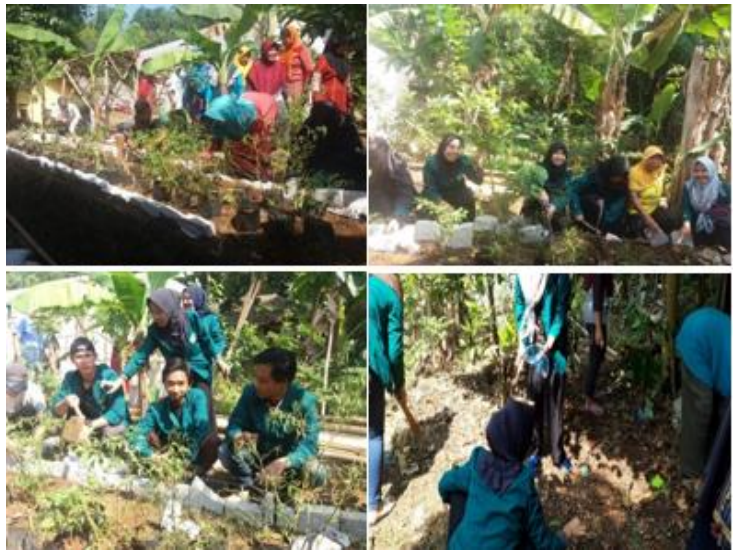

\section{Pembuatan TOGA (Tanaman Obat Keluarga)}

Adanya pembangunan POSYANDU di Kp.Pasir Iis Rt.18/04 membuat kami ingin ikut serta membantu dengan memberikan gagasan dan tenaga yakni membuat program TOGA dimana program ini memanfaatkan sedikit lahan yang ada di posyandu untuk ditanami beberapa jenisa tanaman obat yang nantinya dapat dimanfaatkan oleh masyarakat setempat. tujuan:

- Memberikan ilmu pengetahuan tentang tanaman yang dapat dimanfaatkan sebagai obat 
- Menambah kesadaran masyarakat bahwa di sekitar kita banyak tanaman yang dapat di manfaatkan bagi kesehatan

- Menambah kesadaran masyarakat tentang kesehatan

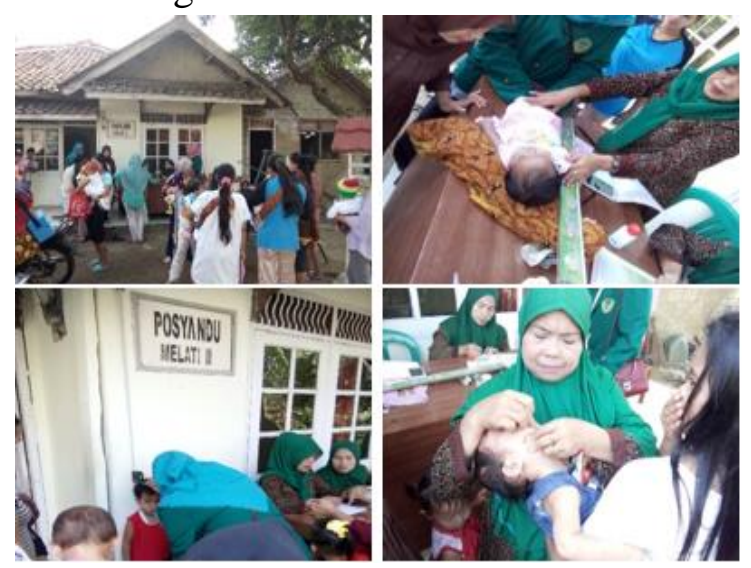

\section{Pengukuran Anak di POSYANDU}

Kegiatan POSYANDU dilakukan satu bulan sekali, karena waktu antara kegiatan POSYANDU dan program kerja yang kami ranjang sama maka kami membantu kegiatan POSYANDU tersebut, tujuan:

\section{KESIMPULAN}

Dengan melaksanakan program kerja KKN ini mahasiswa telah melihat dan menginventasi potensi, kebutuhan dan permasalahan yang ada dan kemudian disesuaikan dengan keprofesian dan kemampuan yang ada. walaupun tidak semua permasalahan terpecahkan dan tidak semua kebutuhan dapat terpenuhi akan tetapi secara umum kegiatan KKN di Desa Situ Daun ini dapat berjalan dengan lancar dan baik. Progam-program secara umum mendapat tanggapan yang positif dari masyarakat dan mendapat dukungan dari aparat pemerintah desa setempat.

Program kerja yang dilaksanakan dibagi menjadi empat bidang yakni bidang lingkungan dan teknik, bidang pendidikan, bidang ekonomi dan bidang kesehatan.
- Membantu kegiatan PKK

- Memberikan pelayanan untuk ibu dan balita
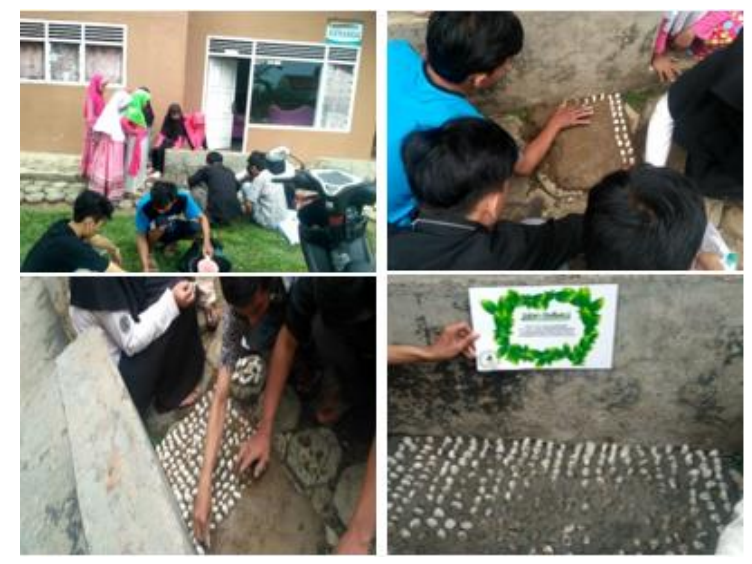

\section{Pembuatan Jalan Refleksi}

Kurangnya sarana dan prasarana di POSYANDU untuk mendukung kesehatan masyarakat maka dengan ini kami membuat program pembuatan jalan refleksi demi meningkatkan kesehatan masyarakat setempat.

tujuan: Memberikan fasilitas kesehatan untuk masyarakat setempat.

Semua program kerja yang dijalankan untuk mengatasi permasalahan baik secara langsung maupun tidak langsung dan memberikan dampak.manfaat baik dalam jangka pendek, menengah, dan jangka pangang. Dampak langsung dan tidak langsung serta dampak fisik dan non fiisk

Seluruh program kerja ditujukan untuk mengatasi masalah, meningkatkan pengetahun, keterampilan dan membangun sikap produktifitas dan mandiri masyarakat Desa Situ Daun Khususnya Kp. Pasir Ipis RT.18/04 untuk mewujudkan Kampung Ramah Lingkungan di Desa Situ Daun Kecamatan Tenjolaya.

\section{Dampak Bagi Masyarakat}

Dari seluruh program kerja yang di jalankan dampak bagi masyarakat 
khususnya di Desa Situ Daun, memiliki dampak berupa dampak jangka pendek, menengah dan jangka panjang, langsung dan tidak langsung serta beberapa bentuk fisik dan non fisik.

1. Dampak jangka Pendek, menengah dan jangka panjang

Dampak jangka pendek hanya dirasakan saat keberadaan kami di Desa Situ Daun. Dampak jangka menengah, dalmpak ini dirasakan pada saat keberadaan kami dan setelahnya namun ada batas waktu program tersebut berakhir . dampak jangka panjang, yakni program yang di bangun memiliki manfaat berkepanjangan bagi masyarakat, program yang di bangun akan mewujudkan tujuan dari KKN yang dijalankan.

2. Dampak Langsung dan Tidak Langsung Program kerja yang dijalankan akan selalu memberikan manfaat baik secara

\section{SARAN}

Pemanfaatan potensi yang ada di Desa Situ Daun harus ditinngkatkan lagi, baik oleh masyarakat, pemerintah desa dan pihak lainnya, agar hasil-hasil kegiatan dari KKN kelompok 3 dapat terus dirasakan manfaatnya oleh masayarakat. langsung maupun tidak langsung. Dampak secara langsung merupakan dampak atau manfaat yang dapat langsung di rasakan oleh masyarakat, dampak tidak langsung yakni hal yang dirasakan oleh seseorang dari perubahan tingkah laku seseorang yang memberikan manfaat kepadanya.

3. Dampak Fisik dan Non Fisik dan non fisik

Dampak fisik merupakan dampak yang dapat terlihat oleh indra penglihatan, sedangkan dampak non fisik yakni suatu kepuasan rohani yang tidak dapat dilihat oleh indra penglihatan namun hanya dapat dirasakan oleh individu itu sendiri contohnya seperti kegiatan seminar, pelatihan, training motivasi dan lainnya yang memberikan dampak kepuasan tersendiri.

Diperlukannya ada tindak lanjut dari berbagai pihak, baik dari pemerintah daerah maupun pihak lainnya yang memiliki tujuan yang sama yakni membangun kampung ramah lingkungan dengan perekonomian yanng sejahtera. 


\section{REFEREENSI}

Septiani dan Yuliastuti 2015 Perwujudan Kelurahan Ramah Lingkungan (Studi Kasus: Kelurahan Krapyak, Desa Semarang) Volume 3 No. 2

Umi Chotimah, 2015 Membangun Karakter Peserta Didik Melalui Penerapan Beberapa Alternatif Pendekatan Pembelajaran

Muflihatul Maulidiyyah Sekripsi 2015 Pendekatan Komunikasi Organisasi Dalam Membangun Aspek Profesional (Studi Deskriptif Kualitatif Pada Tim Gerai Pt. Aseli Dagadu Djokdja)

Siagian.2005.Manajemen Sumber Daya Manusia. Jakarta:PT.Bumi Aksara

Kasmir dan Jakfar.2008.Study Kelayakan Bisnis.Jakarta:Kencana
Data dan Profil Desa Situ Daun. Oleh kantor Desa Situ Daun

Survei Lokasi (Agustus 2018) Desa Situ Daun

Wawancara (Agustus 2018) Desa Sittu Daun

Internet :

http://blh.bogorkab.go.id/index.php/multisi te/page/1436 (di akses 14 September 2018)

https://id.wikipedia.org/wiki/Produktivitas (di akses 14 September 2018)

https://agusseptianheryanto.wordpress.com /2013/11/05/pendekatan-manajemensumber-daya-manusia (di akses 14 September 2018). 